\title{
Právní regulace cestování do zahraničí v letech 1848-1989 (normativní přehled)
}

\author{
Jan Rychlík
}

Filozofická fakulta, Univerzita Karlova

Kontaktni e-mail: jan.rychlik@ff.cuni.cz

\section{Legal Regulation of Travelling Abroad between 1848 and 1989 (normative overview)}

\begin{abstract}
:
The essay describes the normative analysis of regulations connected with travels abroad from Austria-Hungary and Czechoslovakia from the middle of the 19th century until 1989. It shows, that the second half of the 19th century, the liberal era, was a period of unlimited freedom of movement between states. This era was terminated at the beginning of WW I. After WWI the freedom of movement was restored in Czechoslovakia, but various restrictions remained partially in force throughout the whole inter-war period. During WW II, naturally, international travel for private purposes was not allowed. After WWII freedom of travel was not restored in Czechoslovakia, but the restrictions differed in various periods culminating in the years 1949-1953, when Czechoslovak citizens were forbidden to travel abroad for private purposes at all. Freedom of travel was fully restored on 4 December 1989.
\end{abstract}

\section{Keywords:}

travels abroad; travel documents; Austria-Hungary; Czechoslovakia

\section{Klíčová slova:}

cestování do zahraničí; cestovní doklady; Rakousko-Uhersko; Československo

DOI: $10.14712 / 2464689 X .2018 .21$ 
Otázkám pasového práva nebyla doposud u nás věnována patřičná pozornost. V době první republiky publikoval několik př́spěvků na toto téma Vratislav Kalousek (1883-1936), odborový rada v ministerstvu vnitra. ${ }^{1}$ Protože po roce 1945 byly soukromé cesty do zahraničí výrazně omezeny a v letech 1949-1953 vůbec zakázány, nebylo pochopitelně téma pasové politiky v historické a ani právnické literatuře vhodným tématem. Po roce 1989 se téma částečně vrátilo především do bádání o dějinách cestovního ruchu ${ }^{2}$ a migrace obyvatelstva obecně. ${ }^{3}$ Pozornost regulaci pohybu obyvatelstva byla věnována spíše v sousedních státech - Polsku a Mad'arsku. ${ }^{4}$

Do revoluce 1848 byl pohyb obyvatelstva reglementován různými předpisy. Každý cestující po území monarchie musel mít pas, který poddaným vydávala příslušná vrchnostenská kancelár̆, měšt’anům magistrát jejich města a ostatním obyvatelům státní úruady (krajské úřady, gubernium, případně u vysoké šlechty a duchovenstva přímo císařská kancelář). Pro cesty do jiné korunní země musel být pas potvrzen krajským úřadem. Pro cesty do zahraničí a tzv. nekonskripčních zemí (tj. do zemí, kde se neprováděly pravidelné odvody, tj. Uhry, Benátsko, Lombardie, Tyrolsko a Vorarlberg) vydávalo pasy přímo zemské gubernium, avšak krátkodobé cesty do těchto zemí i do zahraničí v rámci pohraničního styku bylo možné zpravidla uskutečnit i na obyčejný vnitrostátní pas, pokud byl místním státním úradem pro takovou cestu potvrzen. Každý žadatel o pas do zahraničí byl pečlivě prověřován z hlediska politického, obecně kriminálního a fiskálního (tj. nesměl mít nedoplatky na daních či dávkách) a z hlediska povinnosti eventuálního odvodu. Byl-li však už jednou prověřen a nebyly-li u něj shledány žádné závady, nebyl už prověřován $\mathrm{v}$ př́padě dalších cest. Na vydání cestovního pasu k cestě do ciziny neměl žadatel právní nárok, o povolení cesty rozhodoval státní zájem (Staatsnutz), ale na druhé straně - na rozdíl od období komunistické diktatury - bezdůvodně stát vydání pasu neodmítal. Kontrola pasů se prováděla nejen na státních hranicích, ale často i na hranicích zemských (především na hranici s Uhrami) a někdy i ve vnitrozemí např. při nástupu do poštovních vozů přepravujících cestující, do vlaku, na lod' apod. ${ }^{5}$

Revoluce 1848-1849 se pasového systému zásadně nedotkla. Právo na volný pohyb a svobodný pohyb ze země bylo ovšem pojato jak do nikdy neschválené kroměřížské ústavy, tak do oktrojované Stadionovy ústavy, která v § 25 zaručovala volný pohyb po území rríše a omezení vystěhovalectví připouštěla jen z důvodů vojenské služby. V praxi se však - také zřejmě s ohledem na zrušení Stadionovy ústavy 31. prosince 1851 - nic nezměnilo a nadále platily předpisy z doby Metternichova absolutismu s tím rozdílem, že

1 KALOUSEK, V. Zákon o cestovních pasech. Věstník ministerstva vnitra, 1928, roč. 10, č. 5, s. $132-137$. Kalousek je rovněž autorem hesel „,cestování do ciziny“ a „pasy cestovní“ v Slovníku veřejného práva československého.

2 Viz např. ŠTEMBERK, J. a kol. Kapitoly z dějin cestovního ruchu. Praha: Vysoká škola obchodní, 2012.

3 ZUDOVÁ-LEŠKOVÁ, Z. et al. Resettlement and Extermination of the Populations. A Syndrom of Modern History. Prague: Historický ústav, 2015; RYCHLÍK, J. Cestování do ciziny v habsburské monarchii a v Československu. Pasová, vízová a vystěhovalecká politika 1848-1989. Praha: Ústav pro soudobé dějiny AV ČR, 2007.

4 STOLA, D. Kraj bez wyjścia? Warszawa: PAN-IPN, 2010. BENCSIK, P. - NAGY, G. A magyar úti okmányok története 1945-1989. Budapest: Felelös kiadó, 2005.

5 HLAVAČKA, M. Ta pravá mobilita: cestování. In: Mezi časy. Kultura a uměni v českých zemích kolem roku 1800. Sborník př́spěvků z 19. ročníku sympozia k problematice 19. století. Plzeň 4.-6. 3. 1999. Praha: KLP-Koniasch Latin Press, 2000, s. 329-339. 
v důsledku zrušení poddanství a tím i patrimoniální správy vydávaly nyní pasy pro všechny osoby státní úřady.

Nový pasový systém byl zaveden v roce 1857. Císařským nařízením z 9. února č. 31 ř́ršského zákoníku (ř. z.) byly zrušeny vnitřní pasové kontroly, takže kontrola pasů měla být napříště prováděna jen na vnějších hranicích habsburské říše. Na nařízení navazovala společná vyhláška ministerstva zahraničních věcí, vnitra, obchodu, nejvyššího policejního úřadu a vrchního armádního velitelství z 15. února č. 32/1857 ř. z., kterým byl nový pasový systém specifikován. Pro cesty uvnitř ř́íše nebyl pas zapotřebí, avšak každý cestující měl mít u sebe nějakou úřrední legitimaci, kterou mohl prokázat svou totožnost. U obyvatel pohraničního území bylo možné na takovouto legitimaci potvrzenou státním úřadem překračovat i státní hranice a pohybovat se v pohraničí sousedního státu a také návštěvníkům pohraničních území mohl pohraniční úřad legitimaci ověřit ke krátkodobému výjezdu za hranice. Jinak k cestám do zahraničí byl každý cestující povinen mít cestovní pas, který vydávalo bud' ministerstvo zahraničních věcí ve Vídni, nebo zemská místodržitelství anebo s jejich souhlasem představení krajských úřadů. ${ }^{6}$ Každá osoba měla mít zásadně vlastní pas, avšak manželka a nezletilé děti mohly být zapsány do pasu manžela, pokud cestovaly s ním společně. Odepření pasu bylo možné u osob, které byly soudem nebo úřadem omezeny ve volnosti pohybu, nebo u osob nepožívajících úplných občanských a osobních práv, resp. nesvéprávných, pokud nepředložily souhlas opatrovníka či zákonného zástupce. Cizinci, hodlající cestovat do Rakouska, museli mít pas vystavený úřadem svého domovského státu a, nebylo-li určeno jinak, musel být tento pas opatřen písemnou doložkou rakouského konzulátu nebo zastupitelského úřadu v zahraničí, tj. musel mít vízum.

Pád absolutismu a obnovení ústavnosti v Rakousku vedly k faktickému uvolnění povinnosti mít k cestě do ciziny cestovní pas (tzv. Paszwang). Od roku 1860 bylo možné cestovat i do zahraničí na služební průkazy či pracovní knížky, pokud byly opatřeny doložkou o povolení nositele překročit hranice od okresního úřadu či policejního ředitelství. ${ }^{7} \mathrm{~V}$ roce 1859 přistoupilo Rakousko k pasové konvenci států Německého spolku podepsané 22. rríjna 1850 v Drážd'anech. Drážd'anská konvence zaváděla volný cestovní styk po zemích Německého spolku a předpokládala postupné zrušení pasových kontrol na vnitroněmeckých hranicích. Hranice těchto zemí bylo možné překračovat bez pasu a bez víz jen na základě jednoduché pasové legitimace (Paßkarte). V Rakousku byl systém volného pohybu se státy Německého spolku i některými dalšími zeměmi (Belgie, Nizozemí, Švýcarsko, skandinávské země) plně implementován v letech 1862-1863. ${ }^{8}$ Konečně 6. listopadu 1865 bylo vydáno císařské nařízení č. 116/1865 ř. z., kterým se rušily pasové kontroly na vnějších hranicích říše, čímž se povinnost mít cestovní pas - byt' formálně nebyla zrušena - stala iluzorní. Reálně cestující potřeboval pas jen tehdy, pokud to od něj vyžadovaly státy, do nichž cestoval. Většina států tehdejší Evropy postupně do konce století povinnost vykazovat se pasem zrušila. Koncem 19. století pas od cizinců v Evropě

\footnotetext{
6 V souvislosti s postupným rušením krajských úřadů přešla tato pravomoc na úřady okresní. V Uhrách vydávali pasy správci správních obvodů zřizených po porážce revoluce 1848-1849 anebo později správci žup.

7 Viz nařízení č. 66/1860 ř. z. ze dne 14. 3. 1860 a nařízení č. 129/1860 ř. z. ze dne 23. 5. 1860.

8 Viz vyhlášky č. 37/1862 ř. z., č. 58/1862 ř. z., č. 84/1862 ř. z., č. 57/1863 ř. z.
} 
striktně vyžadovalo pouze Bulharsko, Rumunsko, Rusko a osmanská říše. Rusko a osmanská říše navíc vyžadovaly ke vstupu vízum. ${ }^{9}$

Veškeré pasové předpisy byly sjednoceny v meziministerské vyhlášce z 10 . května 1867 č. 80/1867 ř. z. Změny oproti dosavadnímu stavu vyplývaly spíše z reforem správního systému a v důsledném oddělení soudnictví od správy na úrovni okresů. K cestám do ciziny měl mít každý občan platný cestovní pas, avšak pracovní knížky, př́ípadně další podobné průkazy, pokud byly ověřeny a opatřeny doložkou opravňující k cestě do ciziny, mohly být použity místo cestovního pasu. Pas nepotřebovali námořníci a lodníci, pokud měli plaveckou knížku, rovněž jej nepotřebovali obyvatelé pohraničních území ke krátkodobému překračování hranic: jim stačilo osvědčení vydávané okresními hejtmanstvími př́islušného pohraničního okresu. Tytéž úřady a také státní policejní úřady v pohraničních, především lázeňských městech, mohly podobná osvědčení pro malý pohraniční styk vydávat i návštěvníkům a turistům (§ 3). Pasy se vydávaly maximálně na tři roky, pasy nahrazující doklady vždy jen do konce kalendářního roku, v němž byly vydány (§ 4). Cestovní pasy vydávala okresní hejtmanství, v městech se zvláštním statutem městský magistrát. Pokud bylo ale v magistrátním městě zřízeno císařsko-královské policejní ředitelství, přecházelo oprávnění vydávat pasy automaticky na ně ( $\$ 5$ ). Vyhláška převzala beze změny ustanovení ohledně práva úřadu odmítnout vydání pasu osobám, které jsou soudem nebo úřadem omezeny ve volnosti cestovat, anebo nepožívají úplných občanských práv ( 15 ). Císařské nařízení č. 116/1865 ř. z. o zrušení pasových kontrol na hranicích ř́íse nebylo vyhláškou č. 80/1867 ř. z. dotčeno a zůstalo v platnosti.

V roce 1866 prohrálo Rakousko válku s Pruskem, následkem čehož došlo k rozpuštění Německého spolku; místo něj vznikl mnohem centralizovanější Severoněmecký spolek pod vedením Pruska, do kterého nepatřilo Rakousko a státy ležící na jih od řeky Mohan (Main). Pro Severoněmecký spolek byl 12. října 1867 vydán zvláštní pasový zákon (Gesetz über Paßwesen, zkráceně Paßgesetz). ${ }^{10}$ Zákon v $\S 1$ ustanovoval, že v době míru nebo pokud nebyl vyhlášen výjimečný stav, není pro překročení hranic zemí spolku ani k cestám do jiných zemí cestovní pas zapotřebí. Platnost zákona byla po sjednocení Německa v roce 1871 rozšířena na celé území Německé rríše. Protože nadále platilo ustanovení drážd’anské konvence o volném pohybu po území jeho členů, zůstala i po sjednocení Německa rakousko-německá hranice volně průchodná a k cestě z Rakousko-Uherska do Německa či z Německa do Rakousko-Uherska nebyl pas zapotřebí.

Sporná byla v Rakousku otázka - s ohledem na formulaci $§ 15$ meziministerské pasové vyhlášky - zda je cestování do ciziny právem občana. Šlo zde především o vztah mezi oprávněním úřadu odmítnout občanovi vydat cestovní pas a právem občana vystěhovat se ze země, které bylo zaručeno v čl. 4 Základního zákona o všeobecných právech státních občanů z 21. prosince 1867 (č. 142/1867 ř. z.). Říšský soud, který měl v Předlitavsku postavení soudu ústavního, nakonec rozhodl, že odmítnutí vydání pasu není porušením ústavně zaručeného práva na vystěhování, a že tedy právo vycestovat do ciziny občan zaručeno nemá. ${ }^{11}$ Jak je nicméně z předcházejícího výkladu zřejmé, šlo o spíše teoretickou otázku.

9 V̌̃eobecný slovník právní. III. Praha 1898, s. 34-39.

10 Bundesgesetzblatt des Norddeutschen Bundes vom 12 October 1867, s. 33.

11 KALOUSEK, Zákon o cestovních pasech, s. 132. 
V Uhrách byl 11. března 1903 přijat samostatný pasový zákon (zák. čl. VI/1903). ${ }^{12}$ Ustanovení byla obdobná, jako v zákoně Severoněmeckého spolku z roku 1867: k cestám uvnitř uherského státu ani k cestám do ciziny (at' už do Předlitavska anebo na území mimo Rakousko-Uhersko) nebyl v době míru pas zapotřebí (§ 1). Pasy vydávaly župní úřady (konkrétně podžupan), ve městech vyňatých z působnosti žup policejní kapitanáty, v Budapešti Hlavní policejní kapitanát a v Rijece úřad královského místodržícího.

První světová válka znamenala konec svobody cestování. V zemi byl vyhlášen výjimečný stav a na jeho základě byly postupně zaváděny přísné pasové předpisy. Osobám v branném věku bylo už 25. července 1914 nařízením č. 166/1914 ř. z. zakázáno cestovat do ciziny, výjimky mohlo povolit místodržitelství po dohodě s vojenským sborovým nebo zeměbraneckým velitelstvím. Byla zavedena všeobecná pasová povinnost. Státní hranici říše, pokud probíhala $\mathrm{v}$ místech blízkých $\mathrm{k}$ oblasti válečných operací nebo v místech takovými operacemi ohrožených, bylo zakázáno překračovat bez pasu a jinde než na stanovených přechodech. Tato opatření byla nejprve vnímána jako dočasná a místně omezená a byla zavedena 25. července 1914 v Dalmácii13 a 31. července 1914 v Haliči a Bukovině, ${ }^{14}$ avšak nařízením z 15 . ledna 1915 č. 11/1915 ř. z. byla zavedena už trvale na celé délce řŕšské hranice včetně hranic $\mathrm{s}$ neutrálními nebo neválčícími státy. ${ }^{15}$ Podle nařízení z 26. září 1916 č. 329/1916 ř. z. směly být cestovní pasy vydávány na dobu nejvýše jednoho roku a nanejvýše na tři cesty, a to výhradně k nutným a doložitelným účelům, přičemž tento účel cesty musel být v pase uveden. I během platnosti pasu si ke každé cestě držitel musel opatřit výjezdní doložku od vydávajícího pasového úřadu.

Centrální poloha českých zemí a jejich dlouhá hranice se spojeneckým Německem na druhé straně nedovolovala prakticky úplné uzavření hranic a podobná situace byla i na rakousko-bavorské hranici. Proto nařízení č. 11/1915 ř. z. obsahovalo zmocnění pro místodržitele jednotlivých zemí, aby podle místních podmínek povolili v dohodě s místním vojenským velitelstvím úlevy pro malý pohraniční styk. V Čechách se tak stalo místodržitelskou vyhláškou z 13. února $1915 .{ }^{16}$ Osoby usedlé po obou stranách hranic mohly na základě pracovních či potvrzených čeledních knížek přestupovat státní hranici, a to i mimo stanovený přechod. Ale už o rok později byla praxe podstatně ztížena. Místodržitelem byly vydány samostatné předpisy pro česko-bavorskou, ${ }^{17}$ česko-saskou ${ }^{18}$ a česko-pruskou ${ }^{19}$ hranici, byt' způsob regulace byl obdobný: oproti dosavadnímu stavu se malý pohraniční styk (MPS) vztahoval jen na protilehlé celní okresy a mohli jej využívat výhradně rakouští, uherští a němečtí občané. Přechod hranic byl možný jen na stanovených přechodech a jen na základě Osvědčení pro malý pohraniční styk opatřený fotografií. Zvláštní úlevy platily

\footnotetext{
12 Slovenské znění zákona viz: Sbierka krajinských zákonov na rok 1903. Budapest, 1903, s. 48-52.

13 Nařízení č. 159/1914 ř. z.

14 Nařizení č. 187/1914 ř. z.

15 Nařízení bylo doplněno nař. č. 124/1915 ř. z. a č. 334/1915 ř. z. a formálně se týkalo jen předlitavského úseku hranic Rakouska-Uherska; i uherská vláda ovšem vydala obdobná omezující nařízení č. 185/1915 a č. 1725/1915 pro uherský úsek.

16 Zemský zákoník pro království České (z. z. č.), č. 9/1915 z. z. č.

17 Vyhl. č. 44/1916 z. z. č. a č. 63/1916 z. z. č.

18 Vyhl. č. 77/1916 z. z. č.

19 Vyhl. č. $103 / 1916$ z. z. č.
} 
od roku 1917 pro překračování hranice v říční plavbě na Labi, kde bylo tak jako doposud možné překračovat hranici na plaveckou knížku. ${ }^{20}$

Vznik Československé republiky nejprve nejenže neodstranil překážky v cestování, ale naopak je ještě zpř́ísnil. Vládním nařízením z 22. prosince 1918 č. 87 Sb. musel totiž žadatel o pas doložit, že nedluží žádné nedoplatky na daních a složit kauci na daně splatné v době trvání cesty. ${ }^{21}$ Vlastní vydávání pasů bylo regulováno vládním nařízením z 9 . června 1921 č. $215 \mathrm{Sb}$., které bylo vydáno na základě zmocnění obsažených v císařském nařízení č. 116/1865 ř. z. a uherském zák. čl. VI/1903. V podstatě byl zachován dosavadní systém, podle kterého pasy vydávaly politické úrady první instance (tj. okresní úřady a policejní ředitelství) a ve druhé instanci zemská politická správa. Nařízení stanovovalo formu pasu, neurčovalo však vůbec podmínky, za nichž mohlo být jeho vydání odmítnuto. Odmítnutí vydání pasu bylo regulováno podzákonnými předpisy neopírajícími se vlastně o žádné zmocnění, přičemž s odmítnutím vydání pasu se často setkávali hlavně komunisté, pokud chtěli cestovat do SSSR.

Vznikem Československa vznikly nové hranice tam, kde doposud nebyly, což si vyžádalo úpravu malého pohraničního styku. Na nově vzniklé hranici s Rakouskem byl zaveden malý pohraniční styk nařízením zemské politické správy č. 233/1919 Sb., na hranici s Polskem se tak stalo nařízením zemské politické správy v Opavě č. XII-1960 z 27. ř́ijna 1920. Na slovenském úseku hranic s Polskem byl pohraniční styk regulován nařízením ministra s plnou mocí pro správu Slovenska a na Podkarpatské Rusi nařízením viceguvernéra a šéfa politické správy, který také vydal vyhlášku o malém pohraničním styku s Rumunskem. S Mad'arskem malý pohraniční styk zaveden nebyl. Pokud jde o hranici s Německem, v platnosti zůstaly předpisy o malém pohraničním styku z doby války. Během dvacátých let byly postupně uzavřeny dohody o malém pohraničním styku se všemi sousedními státy, byt' stupeň regulace byl různý: nejliberálnější byl pohraniční styk s Německem, regulovaný vyhláškou ministra vnitra z 27. dubna 1928 (č. 66/1928 Sb.), poté s Rakouskem (vyhl. 68/1929 Sb.) a Polskem, s nímž byla vedle dohody o malém pohraničním styku (č. 238/1925 Sb.) uzavřena ještě další dohoda umožňující překračovat hranici v turistických oblastech na základě ověřené legitimace turistických spolků (č. 80/1926 Sb.). Mnohem omezenější byl pohraniční styk s Rumunskem (č. 44/1926 Sb.), protože na rozdíl od tř́i předešlých států neumožňoval překračování hranic pro turisty. Ještě omezenější byl pohraniční styk s Mad'arskem, kde byl součástí přílohy k obchodní dohodě (č. 120/1927 Sb.). ${ }^{22}$ Definitivní dohoda o malém pohraničním styku s Mad'arskem byla podepsána teprve na sklonku první republiky - 17. listopadu 1937 - a platila až od roku 1938 (č. 53/1938 Sb.).

Zákon o cestovních pasech (pasový zákon) byl přijat Národním shromážděním po mnohých odkladech teprve 29. března 1928 a byl publikován ve Sbírce zákonů a nařízení pod číslem 55. Oproti dosavadnímu stavu nedošlo k zásadním změnám, pokud jde o vydávání cestovních pasů - ty nadále vydávaly československým občanům politické úruady I. stoli-

20 Vyhl. č. 56/1917 z. z. č.

21 Srv. prováděcí nařízení č. 46/1919 Sb.

22 Podrobněji viz KALOUSEK, V. Cestování do ciziny. In: Slovník verejného práva československého, Sv. I. Brno, 1929, s. 155-159, též: RYCHLÍK, J. Severní hranice Čech a pohraniční styk se Saskem a Pruskem, resp. Polskem. In: Život na československých hranicích a jejich překračování v letech 1945-1949. PrahaLiberec: ÚSTR - TUL, 2017, s. 87-90. 
ce, přičemž zemský úruad jako úřad II. stolice byl úřadem odvolacím a současně i úřadem, který byl oprávněn vydávat cestovní průkazy na způsob pasů osobám bez státní příslušnosti. Z rozhodnutí zemského úřadu bylo možné odvolání $\mathrm{k}$ ministerstvu vnitra jako ke třetí a nejvyšší instanci. Změna nastala v tom, že zákon definoval právo občana na vydání cestovního pasu, jehož nevydání bylo možné jen z taxativně vymezených důvodů. Tyto důvody byly uvedeny v $\S 7$ a byly tyto: a) nesvéprávnost osoby, pokud nebyl předložen souhlas zákonného zástupce, b) zahájení vyšetřování pro trestný čin stíhaný z povinnosti úřední, pokud zákon stanovil trest delší než 14 dní nebo pokutu vyšší než 5000 Kč, anebo odsouzení pro takový čin, jestliže trest ještě nebyl vykonán, c) omezení pohybu z rozhodnutí soudu nebo politického úřadu, d) důležitý zájem státní bezpečnosti nebo hospodářský zájem republiky, nebo „světoběžnictví žadatele ze zvyku“, a e) dluhy na daních nebo jiných veřejných dávkách ve značné výši, jejichž nezaplacením by mohla vzniknout státu nebo veřejné korporaci újma. To ale neplatilo, jestliže za daně či dávky byla složena záruka.

Jak je z uvedeného přehledu vidět, nejproblematičtější byl bod d), který umožňoval odepřít vydání pasu nebo jeho odebrání, jestliže by cesta mohla ohrozit státní nebo hospodářský zájem. Tento bod totiž mohl být lehce zneužitelný, na což při schvalování zákona opakovaně poukazovala opozice. Také pojem „světoběžník ze zvyku“ byl velmi vágní a umožňoval různý výklad. S odmítnutím vydání pasu s poukazem na ustanovení $§ 7 \mathrm{~d}$ ) se setkávali především žadatelé hodlající cestovat do SSSR, na prvním místě pak českoslovenští komunisté. Běžné československé pasy totiž pro cesty do tohoto státu až do roku 1934 neplatily a o rozšśřrení platnosti pro SSSR bylo třeba žádat. Jinak ovšem můžeme říci, že cestování bylo v období první republiky svobodné a odmítnutí vydání pasu bylo spíše výjimkou. Navíc politickému zneužívání tohoto odstavce částečně bránil judikát Nejvyššího správního soudu. Ten pod číslem 13787 dne 26. září 1931 ke stížnosti občana na nevydání cestovního pasu rozhodl, že „odpírá-li úřad cestovní pas z důvodu, že žadatelova cesta by mohla ohroziti důležité zájmy státní bezpečnosti, musí v rozhodnutí uvésti konkrétní skutečnosti, na základě nichž dospěl k tomuto úsudku““.23

Nacistická okupace a vznik Protektorátu Čechy a Morava znamenaly konec svobody cestování, podobně jako tomu bylo v roce 1914. Protektorát byl integrální součástí Německé říše, která nad ním od počátku vykonávala svou pasovou jurisdikci. Hranice protektorátu byly hned 16. března 1939 uzavřeny pro běžný cestovní styk. Vycestování z protektorátu bylo sice až do září 1939 možné na staré československé pasy, avšak podmínkou cesty bylo zvláštní výjezdní povolení od německých úřadů, tzv. Durchlaßschein. Nařízením říšského ministra vnitra z 10. záríi 1939 byly na protektorát plně rozšířeny německé pasové předpisy. ${ }^{24}$ I protektorátním občanům cestujícím do zahraničí byly vydávány říšskoněmecké pasy, na které bylo opět ke každé cestě třeba získat výjezdní povolení. Oboje vydávaly úřady vrchních zemských radů (Oberlandraty). Výdej pasů byl oběžníkem říšského protektora pro oberlandraty z 26. června 1940 omezen jen na služební cesty a jen ve výjimečných prrípadech na cesty $z$ vážných osobních důvodů. ${ }^{25}$ Zajímavé přitom je, že volně cestovat nebylo možné ani z Protektorátu do ostatního území říše, ačkoliv Protektorát

23 RADEK, O. Vybraná rozhodnutí Nejvyššiho správního soudu v letech 1918-1948 a jejich využití v současné aplikačni praxi. Praha: Linde, 2001, s. 33.

24 Reichsgesetzblatt (RGBl). 1939, I., S. 1739.

25 NA ČR, f. Policejní ředitelství Praha II - stanice a komisariáty, k. 7, inv. č. 1102, oběžník Policejního ředitelství Praha z 26. 7. 1940, čj. 18.397 prez. 
byl její součástí. Na Slovensku naproti tomu platil po celou dobu války prvorepublikový zákon č. 55/1928 Sb. a až do vypuknutí války nebyly slovenským občanům kladeny žádné překážky, pokud chtěli vycestovat. S vypuknutím druhé světové války byla i na Slovensku zavedena výjezdní povolení nutná ke každému vycestování, která vydávaly okresní úřady nebo policejní ředitelství. Cesty do neutrálních států byly od roku 1940 zpravidla předkládány $\mathrm{k}$ vyjádření Ústředně státní bezpečnosti (ÚŠB).

Ve veřejnosti přežívá představa, že poválečné uzavření hranic je teprve záležitostí únorového převratu, avšak takovýto názor je mylný. Cestovní styk nebyl volný ani v letech 1945-1948, byt' po formální stránce platil nadále zákon č. 55/1928 Sb. K běžným cestám do ciziny se cestovní pasy, jejichž vydávání převzaly bez zákonného podkladu od okresních úřadů (resp. jejich právních nástupců - okresních národních výborů) výhradně ředitelství Národní bezpečnosti (policejní ředitelství), nevydávaly. K odůvodnění odmítnutí vydání pasu sloužil paušálně $§ 7$ d) pasového zákona, který byl nově interpretován v tom smyslu, že cestovní do zahraničí znamená úbytek deviz i pracovní síly, což ohrožuje důležitý hospodářský zájem republiky. Povolovány byly pouze cesty pracovní a obchodní, přičemž žadatel musel opodstatněnost cesty dokázat, léčebné pobyty u moře na doporučení odborného lékaře a soukromé cesty z vážných osobních důvodů. Únorový převrat podmínky pro vydání pasu ještě zpř́ísnil; navíc už 23. února 1948 vydalo ministerstvo vnitra příkaz pasovým kontrolám nepropouštět přes státní hranici osoby, které nemají v cestovním pase vepsáno výjezdní povolení od oddělení III/6 ministerstva vnitra v Praze, anebo VII. odboru pověřenectva vnitra v Bratislavě. ${ }^{26}$ Systém výjezdních povolení, známých pak pod názvem „výjezdní doložka“, zůstal již trvale v platnosti.

Od podzimu 1948 připravovalo ministerstvo vnitra nový zákon o cestovních pasech, který Národní shromáždění schválilo 23. února 1949 a byl publikován pod č. 53/1949 Sb. Cestovní pasy vydávalo ministerstvo vnitra nebo jiný orgán jím pověřený, diplomatické a zvláštní pasy vydávalo - tak jako doposud - ministerstvo zahraničních věcí. Zákon výslovně stanovoval (§ 2 odst. 5), že ,na vydání, prodloužení časové a rozšíření územní platnosti československého cestovního pasu není právního nároku“. Zákon měl jen rámcový charakter, protože podrobná ustanovení měl určit ministr vnitra vyhláškou v úředním listě. Stalo se tak vyhláškou č. 439/1949 Ú. 1. z 16. března 1949. Podle ní vydávaly cestovní pasy pasové úřady MV v Praze, Brně a Bratislavě, přičemž k vydání pasu bylo třeba vždy přiložit doklad o důležitosti cesty. Pasy se vydávaly na dobu nezbytně nutnou ke splnění účelu cesty, nejdéle ale na dobu pěti let. Důležitější než prováděcí vyhláška ministra vnitra bylo ve skutečnosti usnesení vlády z 1 . března 1949, podle kterého neměly být soukromé cesty do zahraničí (včetně tzv. lidově-demokratických států) vůbec povolovány. ${ }^{27}$ Vládním nařízením č. 125/1951 Sb. ze 17. prosince 1951 byla veškerá pasová agenda formálně přenesena na ministerstvo zahraničních věcí, které vydalo formálně s datem 31 . prosince 1951 také novou prováděcí vyhlášku k pasovému zákonu. ${ }^{28} \mathrm{MZV}$ v Praze se stalo jediným místem pro podávání žádostí z celé republiky; nebylo ovšem žádným tajemstvím, že funguje jen jako sběrna a že o vydávání pasů a výjezdních doložek ve skutečnosti rozhoduje

\footnotetext{
26 HOLUB, O. Výstřely ze zálohy. Praha: Panorama 1978, s. 237.

27 NA ČR, f. Úřad předsednictva vlády (ÚPV) ČSR, 35. schůze vlády, 1. 3. 1949, bod 40.

28 Vyhláška č. 2/1952 Ú. 1.
} 
nově zř́zzené ministerstvo národní bezpečnosti (MNB), resp. po jeho zrušení v roce 1953 opět ministerstvo vnitra.

Posun v regulaci cestovního ruchu se v padesátých letech realizoval především podzákonnými normami, a sice usnesením vlády anebo (především) usnesením stranických orgánů. Prvním takovým opatřením bylo usnesení předsednictva vlády z 10. listopadu 1953, kterým byl zrušen zákaz soukromých cest do zahraničí. Zrušení zákazu ale vůbec neznamenalo paušální povolení těchto cest, protože o každé žádosti rozhodovala komise pro záležitosti pasové a vízové složená z ministra vnitra (R. Barák), ministra zahraničních věcí (V. David), ministra zahraničního obchodu (R. Dvořák) a vedoucí mezinárodního oddělení ÚV KSČ (A. Baranová). ${ }^{29}$ Mnohem větší význam mělo o tři roky později usnesení politického byra ÚV KSČ z 16. dubna 1956, podle kterého měly být napříště povolovány občasné soukromé cesty do ostatních tzv. socialistických států na základě pozvání př́ibuzných, hromadné turistické cesty organizované cestovními kancelářemi a ve velmi omezeném rozsahu také návštěvní a organizované turistické cesty do ostatních zemí. ${ }^{30}$ Okruh příbuzných, případně dalších osob, které bylo možné v zahraničí na pozvání navštívit, byl několikrát modifikován. Zásadní změnu a posun přineslo usnesení předsednictva ÚV KSČ z 8. ř́jna 1963 a na ně navazující usnesení vlády z 21. prosince 1963, podle něhož měl být cestovní styk s ostatními socialistickými státy postupně zcela uvolněn a cesty do ostatních států umožněny na pozvání širokého okruhu příbuzných nebo prostřednictvím cestovních kanceláŕí. ${ }^{31}$

Odraz těchto změn v normativních aktech je poměrně dobře patrný: vyhláškou ministra zahraničních věcí z 2. června 1956 č. 114 Ú. 1. bylo podávání žádostí o soukromou nebo turistickou cestu přeneseno z MZV na okresní oddělení Veřejné bezpečnosti, v Praze na městskou správu VB. K takovýmto krátkodobým cestám nebyly vydávány cestovní pasy, ale cestovní př́ilohy k občanskému průkazu, v případě turistických zájezdů hromadné zájezdní soupisky. Od roku 1958 o povolování cest rozhodovaly krajské správy VB, v Praze městská správa VB, což bylo legislativně odůvodněno ,účelnou decentralizací“ a formálně opřeno o zmocnění vydané ministrem zahraničních věcí 30. července 1958 č. 117 Ú. 1. Vládním nařízením č. 66/1963 Sb. z 28. srpna 1963 byla veškerá agenda i formálně převedena z MZV zpět na ministerstvo vnitra. Konečně 18 . června 1965 přijalo Národní shromáždění zákon č. 63/1965 Sb., o cestovních dokladech.

Podle své dikce se zákon č. 63/1965 Sb. blížil prvorepublikovému zákonu č. 55/1928 Sb. Opouštěl totiž zásadu vydávání cestovního pasu nebo jiného podobného dokladu na základě volné úvahy státního orgánu a podle potřeb státu a vracel se - přinejmenším po formálně-právní stránce - k nároku občana na takovýto doklad. § 4 odst. 1 zákona určoval taxativně př́ípady, kdy je možné vydání cestovního dokladu (což je širší pojem, než jen cestovní pas) odmítnout, resp. už vydaný doklad odebrat (§ 4 odst. 2). Bylo tak možné učinit občanům, a) jejichž cesta do ciziny by nebyla v souladu se státními zájmy, b) proti nimž je vedeno trestní ř́zení, c) kteří byli odsouzeni pro trestný čin, pokud se na ně nehledí, jako by nebyli odsouzeni, nebo pokud odsouzení nebylo zahlazeno, a d) kteří při pobytu v cizině svým jednáním poškodili dobré jméno Československé socialistické republiky.

29 NA ČR, f. ÚPV, 51. schůze předsednictva vlády 10. 11. 1953, bod 2, čj. V 2820/53 T.

30 NA ČR, f. ÚV KSČ, PB 1954-1962, aj. 112, sv. 94, schůze PB 16. 4. 1956, bod 17.

31 RYCHLÍK, Cestování do ciziny v habsburské monarchii a v Československu 1848-1989, s. 65. 
Na první pohled vidíme, že ustanovení $\S 4$ a) je obdobou ustanovení $\S 7$ d) prvorepublikového pasového zákona, avšak je značně širší a neurčitější. Cesta už nemusela ohrožovat důležitý zájem bezpečnosti státu, stačilo, jestliže nebyla v souladu s jeho zájmem. Také $\S 4$ odst. 1 b) byl koncipován šíře, než tomu bylo za první republiky u $\S 7$ b), protože tehdy odpykáním trestu (a nikoliv až jeho zahlazením) překážka pro vydání pasu pomíjela. Zcela novým důvodem oproti prvorepublikové praxi pak byl odstavec d), tedy ,poškození dobrého jména ČSSR v cizině“, který sice mohl být vnímán jako postih za př́padnou kriminální činnost během pobytu $v$ zahraničí, ale v první řadě měl zřejmě zamezit nežádoucím zahraničním politickým vystoupením. I tak ovšem nový zákon znamenal nesporně pokrok. Problémem byla spíše společná prováděcí vyhláška ministerstva vnitra a ministerstva zahraničních věcí z 23. června 1965 (č. 64/1965 Sb.), která ponechávala v § 3 v platnosti výjezdní doložky, jejichž odepření mohlo nastat z týchž důvodů, jako u vydání cestovního dokladu. V praxi to znamenalo, že každý žadatel musel před cestou požádat ještě o vydání výjezdní doložky. Pro Bulharsko a Mad'arsko byly už od počátku vydávány výjezdní doložky stálé a tato praxe byla do roku 1968 postupně rozširréena na všechny státy Rady vzájemné hospodářské pomoci (RVHP) v souvislosti s rušením vízové povinnosti s těmito státy. ${ }^{32}$ Do ostatních států ovšem byly k soukromým cestám vydávány zpravidla jen jednorázové výjezdní doložky.

V roce 1968 doznalo cestování dalšího uvolnění, byt' legislativně žádné změny přijaty nebyly. Vydávání jednorázových výjezdních doložek se stalo poměrně rychlým procesem, byt žadatel musel předložit pozvání anebo příslib Státní banky československé o prodeji deviz. Akční program KSČ počítal s tím, že bude vydán zcela nový zákon o cestovních dokladech, umožňující volné cestování a neomezený pobyt v zahraničí po dobu platnosti cestovního pasu. ${ }^{33}$ Zákon byl skutečně připravován v gesci ministerstva vnitra. V pracích na něm se pokračovalo ještě v roce 1969 a byl doveden až do paragrafovaného znění, nikdy však schválen nebyl. Naopak, už od podzimu 1968 dochází k opětovnému omezování cest na Západ, byt' rozhodující zlom nastal teprve 8. října 1969 v souvislosti s počátkem „ostré fáze“ normalizace. V uvedený den přijala federální vláda na návrh ministra vnitra Jana Pelnáře a ministra zahraničních věcí Jána Marka usnesení č. 266/1969, kterým měly být naprŕšště soukromé cesty do tzv. kapitalistických států a Jugoslávie povolovány jen na návštěvu nejbližších př́íbuzných žijících v zahraničí legálně anebo na základě př́íslibu deviz Státní banky československé (SBČS). ${ }^{34}$

Usnesení č. 266/1969 bylo vtěleno do vládního nařízení č. 114/1969 Sb. majícího rovněž datum 8. ř́jjna 1969. Vstupovalo v platnost dnem vyhlášení, tj. 9. ř́ína. ${ }^{35}$ Po formální stránce šlo o prováděcí nařízení $\mathrm{k} \S 4$ odst. 1 písm. a), tedy specifikaci důvodů, ve kterých mohlo být vydání cestovního dokladu odepřeno, jelikož cesta nebyla v souladu se státními zájmy. Tyto státní zájmy byly ovšem stanoveny velmi široce: cesta nebyla v souladu se

32 Volný cestovní styk byl zaveden nejprve s Mad'arskem (vyhl. č. 2/1964 Sb.) a s Bulharskem (vyhl. č. 126/1965 Sb.), následně v roce 1967 s NDR (vyhl. č. 101/1967 Sb.) a v roce 1968 s Rumunskem (vyhl. č. 67/1968 Sb.). Cestování do SSSR bylo z hlediska československých předpisů volné, byt' ze sovětské strany bylo u soukromých cest vyžadováno ověřené pozvání (vyhl. č. 128/1969 Sb.). Pozvání (neověřené) bylo vyžadováno i v cestovním styku s Polskem, zcela volný styk zaveden až v roce 1977 (vyhl. č. 59/1977 Sb.).

33 Rok šedesátý osmý v usneseních a dokumentech KSČ. Praha: Svoboda, 1969, s. 118-119.

34 RYCHLÍK, Cestování do ciziny, dok. 15, s. 182-185.

35 Sbírka zákonů ČSSR, ČSR, SSR, částka 37 ze dne 9. 10. 1969. 
státními zájmy, byla-li v rozporu s ochranou bezpečnosti státu, vnitřního pořádku, veřejného zdraví nebo morálky, a dále, šlo-li o cestu a) do států, s nimiž ČSSR neudržuje diplomatické styky, b) k návštěvě státního občana, který se zdržuje v cizině bez povolení československých úřadů, c) občana, proti němuž je veden výkon rozhodnutí pro neplnění vyživovací povinnosti nebo neplnění závazků vůči státu nebo socialistické organizaci, d) občana, jehož jednání nasvědčuje tomu, že hodlá zůstat v cizině po uplynutí doby pobytu v cizině, e) která není devizově kryta. K tomu je ale třeba dodat, že v rozporu s logikou tohoto bodu úhrady došlé ve volně směnitelné měně ze zahraničí na adresu žadatele nebyly považovány za devizové krytí. Dalším důvodem (uvedeným pod písm. f) byla navíc „,esta bez př́slibu deviz, s výjimkou cest za příbuznými v pokolení přímém, sourozenci a manžely, nejde-li o př́ípad uvedený pod písmenem a) - d)“. Na takovýto příslib ovšem nebyl právní nárok, čímž byl faktický stav - alespoň pokud jde o cesty do tzv. nesocialistických států a Jugoslávie - vrácen do doby před platností zákona č. 63/1965 Sb. Vládní nařízení ve skutečnosti likvidovalo samotný smysl zákona, protože jej vykládalo ve smyslu, který zákonodárce v roce 1965 prokazatelně neměl.

Na vládní nařízení č. 114/1969 Sb. navazovala 9. října vydaná společná vyhláška ministerstva vnitra a ministerstva zahraničních věcí č. 115/1969 Sb., kterou se rušila platnost už vydaných, avšak doposud nepoužitých jednorázových výjezdních doložek k soukromým cestám, vyjma stálých doložek do ostatních socialistických států Rady vzájemné hospodářské pomoci. Platnost doposud nepoužitých výjezdních doložek k turistickým cestám v rámci zájezdů cestovních kanceláří (označené přetiskem „TURISTIKA“) se zrušovala k 1. lednu 1970, což bylo zřejmě motivováno zájmem cestovních kanceláří, které by jinak musely vracet klientům peníze za už zaplacené zájezdy.

Vládní usnesení č. 266/1969, resp. vládní nařízení č. 114/1969 Sb., určovalo rámcově směr pasové politiky pro následujících osmnáct let: ve vztahu k cestování do „nepřátelské“ ciziny a částečně také do Jugoslávie šlo o politiku jednoznačně restriktivní, byt' některá opatření, jako např. zákaz návštěv osob zdržujících se ilegálně v zahraničí, striktní odmítání pozvání od jiných osob než blízkých př́ibuzných, či zásada, že cestu do tzv. nesocialistických zemí lze povolit jen jednou ročně, byla od osmdesátých let zmírněna pro osoby v důchodovém věku. Cestování do zemí RVHP naproti tomu na rozdíl od padesátých let za normálních okolností nemělo být zásadně omezováno. V tomto směru byla také koncipována nová prováděcí vyhláška ministerstva vnitra a ministerstva zahraničních věcí ze 13. dubna 1970 č. 44/1970 Sb. Místo dosavadních př́loh k občanskému průkazu pro cesty do ostatních socialistických států ${ }^{36}$ byly nyní vydávány ráádné cestovní pasy na pět let, které ale bez jednorázové výjezdní doložky platily jen k cestám do států Rady vzájemné hospodářské pomoci (Bulharsko, Mad'arsko, NDR, Polsko, Rumunsko, SSSR, později také Mongolsko). Trvalé výjezdní doložky do těchto států byly v roce 1972 nahrazeny tzv. doplňovací známkou a v roce 1980 vůbec zrušeny. ${ }^{37}$ K ostatním cestám byla zapotřebí výjezdní doložka, jejíž vydání bylo vázáno na několik povolení a zpravidla i na devizový př́íslib.

Zbývá dodat, že ani cesty do států RVHP nebyly zcela svobodné, ale podléhaly ekonomickým a politickým výkyvům. V tomto směru je charakteristický cestovní styk s Polskem. V souvislosti s vystoupením Nezávislého odborového svazu „Solidarita“ rozhodlo

36 Tyto př́lohy byly vydávány i nadále v případě, že na vydání cestovního pasu nebyl dostatek času.

37 Vyhl. MV a MZV č. 142/1971 Sb., č. 7/1980 Sb. 
předsednictvo ÚV KSČ 31. října 1980 omezit cesty československých občanů do Polska a polských občanů do Československa na pouhé čtyři výjezdy ročně, přičemž další výjezd (vjezd) byl možný vždy až za tři měsíce. ${ }^{38}$ Usnesením ÚV KSČ ze 4. prosince 1981 byly soukromé cesty do Polska a z Polska s platností od 7. prosince zastaveny vůbec. ${ }^{39}$ Krátce na to (v noci z 12. na 13. prosince 1981) byl sice v Polsku vyhlášen výjimečný stav a hranice uzavřeny polským vojskem, avšak volný styk nebyl z československé strany obnoven ani po zrušení výjimečného stavu 22. července 1983. K částečnému obnovení turistického styku došlo na opakované naléhání polské strany až od 1. srpna 1985, přičemž překročení hranice bylo vázáno bud' na ověřené pozvání nejbližších příbuzných, nebo na zakoupení poukázky (voucheru) na ubytování v registrované cestovní kancelár̆i. Toto jednostranné opatření československé vlády přitom nemělo žádnou právní oporu v platné legislativě, protože dohoda s Polskem o usnadnění turistiky podepsaná ve Varšavě 20. července 1977 (č. 59/1977 Sb.) podobné opatření neumožňovala a formálně nebyla vypovězena a navíc platný zákon o cestovních dokladech a vládní nařízení č. 114/1969 Sb. neumožňovaly zabránit v cestě do Polska československému občanovi, kterému byl vydán platný cestovní pas.

K uvolnění cestování došlo až v souvislosti s československou verzí přestavby. Stalo se tak opět bez jasných legislativních opatření. Usnesení vlády ČSSR č. 252 z 10. září 198740 umožnilo, aby cesty do tzv. nesocialistických států bylo v budoucnu možno konat i za vlastní devizové prostředky. Předpokládalo to, že žadatel bude mít otevřen devizový účet anebo dostane prostředky ze zahraničí. Možnost získat výjezdní doložku i bez devizového príslibu se tak poprvé otevřela v roce 1988, čímž se cestování dostalo zhruba do stejné polohy, v jaké bylo v letech 1965-1969. V roce 1988 začalo také federální ministerstvo vnitra připravovat zrušení výjezdních doložek a zavedení možnosti volného vycestování na pouhý cestovní pas. Př́ípravy se však protáhly a do listopadové revoluce byly výjezdní doložky s platností od 1. záŕí 1989 zrušeny jen pro služební cesty na cestovní pasy vydané pro služební účely.

Zrušení výjezdních doložek se uskutečnilo teprve po revoluci, konkrétně 4. prosince $1989,{ }^{41}$ přičemž tato změna nebyla podepřena žádnou právní normou, takže paradoxně po formální stránce platil nadále nejen zákon č. 63/1965 Sb., ale i normalizační vládní nařízení č. 114/1969 Sb. Změna nastala formálně teprve 15 . května 1991 v podobě zákona č. 216/1991 Sb. o cestovních dokladech, jehož § 1 stanovil jasně: „Občan České a Slovenské Federativní Republiky má právo svobodně vycestovat do zahraničí a právo na svobodný návrat do České a Slovenské Federativní Republiky.“

\footnotetext{
38 RYCHLÍK, Cestování do ciziny, dok. 23, s. 221-227.

39 Tamtéž, dok. 24, s. 228-233.

40 Tamtéž, dok. 26, s. 242-248.

41 Sdělení k cestám do ciziny. Rudé právo, 1. 12. 1989, s. 1, též K cestám do ciziny. Rudé právo, 2. 12. 1989, s. 2 .
} 